\title{
The identification of a novel splicing mutation in $C 1 q B$ in a Japanese family with C1q deficiency: a case report
}

\author{
Yousuke Higuchi ${ }^{1}$, Junya Shimizu ${ }^{1 *}$, Michiyo Hatanaka² ${ }^{2}$ Etsuko Kitano ${ }^{2}$, Hajime Kitamura ${ }^{2}$, Hidetoshi Takada ${ }^{3}$, \\ Masataka Ishimura ${ }^{3}$, Toshiro Hara ${ }^{3}$, Osamu Ohara ${ }^{4}$, Kenji Asagoe ${ }^{5}$ and Toshihide Kubo ${ }^{1}$
}

\begin{abstract}
$\mathrm{Clq}$ deficiency is a rare disease that is associated with a high probability of developing systemic lupus erythematosus. We report a 4-year-old Japanese girl who presented with fever, facial erythema, joint pain, and oral ulceration. Complement deficiencies were suspected because of her persistent hypocomplementemia and normal levels of the complement proteins C3 and C4. We identified a novel homozygous splicing mutation in the C1qB gene, $c .187+1 G>T$, which is the first mutation to be confirmed in a Japanese individual. Because treatment with steroids and immunosuppressive drugs was not effective, we commenced use of fresh frozen plasma to provide C1q supplements. Currently, the patient remains almost asymptomatic, and we are attempting to control the drug dosage and administration intervals of fresh frozen plasma.
\end{abstract}

Keywords: C1q deficiency, Systemic lupus erythematosus, Hypocomplementemia, Novel mutation, Fresh frozen plasma

\section{Background}

The complement system involves a group of proteins that function as part of the immune system. Three complement pathways make up the complement system, the classical, alternative, and lectin pathways. The C1q protein is the first component of the classical pathway and is composed of the $\mathrm{C} 1 \mathrm{qA}$ chain, $\mathrm{C} 1 \mathrm{qB}$ chain, and $\mathrm{C} 1 \mathrm{qC}$ chain, which are encoded by $C 1 q A, C 1 q B$, and $C 1 q C$ genes, respectively [1].

C1q deficiency is a rare disease that is associated with a high probability of developing systemic lupus erythematosus (SLE) $[2,3]$. It is also complicated by cutaneous disease, glomerulonephritis, central nerve system lupus, and recurrent bacterial infection at an early age $[2,4]$. A deficiency of other complement components such as $\mathrm{C} 1 \mathrm{r}, \mathrm{C} 1 \mathrm{~s}, \mathrm{C} 2$, and $\mathrm{C} 4$ is also involved in SLE, with C1q deficiency being the strongest single risk factor for SLE development [5]. The first C1q deficiency-causing mutation was reported by McAdam

\footnotetext{
*Correspondence: junshimi@okayama3.hosp.go.jp

'Department of Pediatrics, National Hospital Organization Okayama Medical Center, 1711-1 Tamasu, Kita-ku, Okayama 701-1192, Japan

Full list of author information is available at the end of the article
}

et al. in 1988 [6]. Today, 14 mutations have been identified, all of which are nonsense or missense mutations [7-9]. Although immunosuppressive therapy is administered to $\mathrm{C} 1 \mathrm{q}$ deficiency patients, there is currently no curative therapy.

We report herein a girl with $\mathrm{C} 1 \mathrm{q}$ deficiency, and the identification of a novel splice site mutation in the C1qB gene, which is the first confirmed genetic mutation in a Japanese individual with C1q deficiency.

\section{Case presentation}

A 4-year-old Japanese girl was referred to our hospital with a three month history of fever, facial erythema, joint pain, and oral ulceration. She had been diagnosed with discoid lupus erythematosus following a skin biopsy at another hospital. Her symptoms were alleviated transiently after the oral administration of prednisolone; however, they relapsed after cessation of treatment. She had no past history of recurrent infections or fevers of unknown origin. Her parents are not consanguineous,

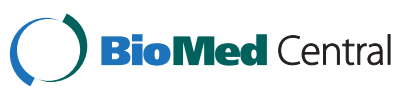

(c) 2013 Higuchi et al.; licensee BioMed Central Ltd. This is an open access article distributed under the terms of the Creative Commons Attribution License (http://creativecommons.org/licenses/by/2.0), which permits unrestricted use, distribution, and reproduction in any medium, provided the original work is properly cited. 
and all other family members, including parents and two brothers, were healthy and had not complained of SLE-like symptoms at that time.

At the first visit to our department, physical examinations revealed low grade fever, scarring facial erythema, oral ulceration, and a chilblain-like rash on the extremities of her limbs (Figure 1). Breath sounds were clear and unlabored. Cardiac examination revealed no murmurs, rubs, or gallops. The abdomen was soft, nontender, and nondistended. Neurological examinations of the cranial nerve, motor strength and coordination, reflexes, gait and sensation were normal. Blood and urine tests for rheumatic fever and other febrile illness revealed elevated inflammatory markers (erythrocyte sedimentation rate (ESR) $65 \mathrm{~mm} / 60 \mathrm{~min}$, C-reactive protein (CRP) $1.32 \mathrm{mg} / \mathrm{dl}$ ), although blood cell count,

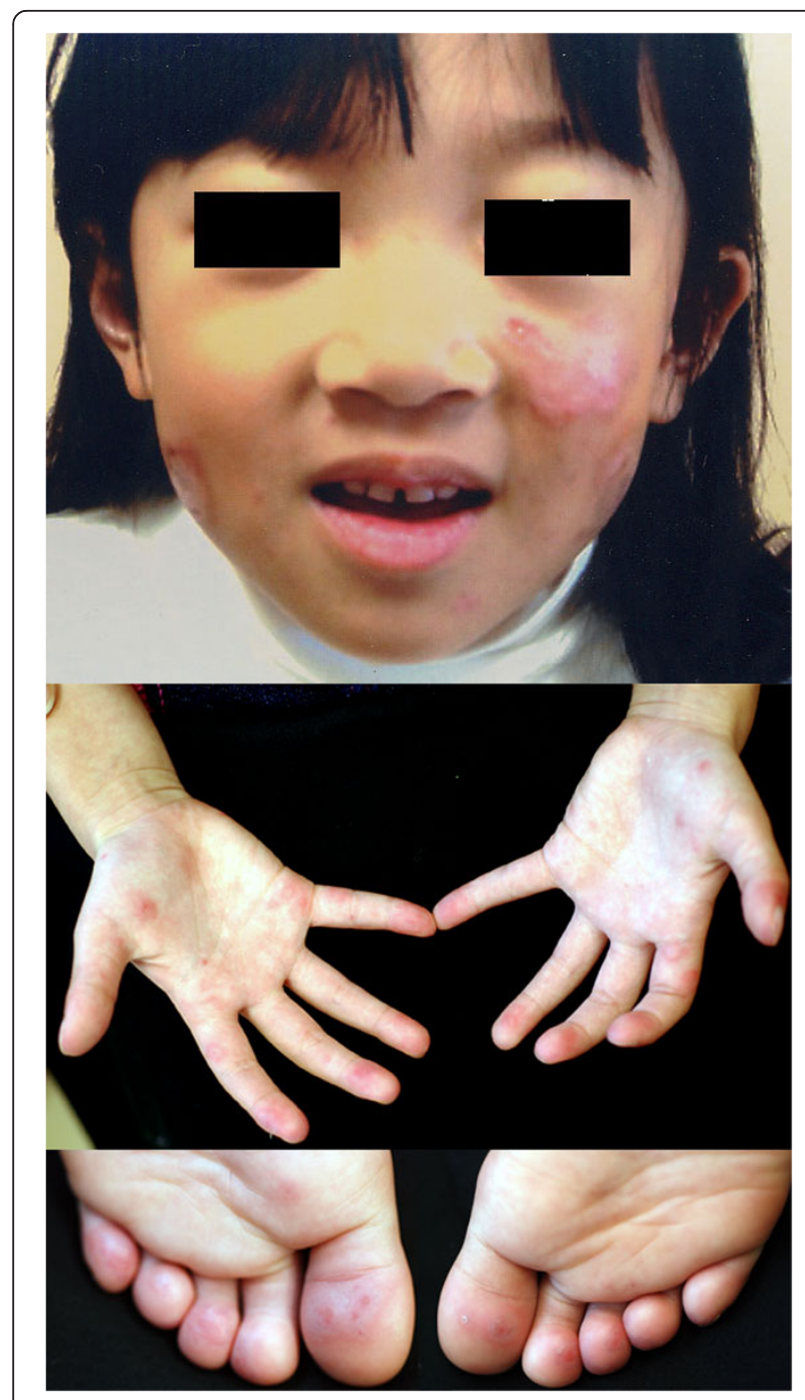

Figure 1 Lupus erythematosus malar skin rash and rash on the hand and foot of our patient. electrolytes, blood urea nitrogen, creatinine, liver function, and urinary tests were all normal (Table 1). Total complement activity (CH50) was not detectable but an immunoturbidimetric assay revealed that $\mathrm{C} 3$ and $\mathrm{C} 4$ levels were within the normal range. Speckled antinuclear antibody and rheumatoid factor were positive, and anti-double stranded DNA IgG antibody levels were negative. A chest computed tomography (CT), echocardiography, magnetic resonance imaging of the brain, and renal biopsy specimen were normal.

Initially, the patient had been diagnosed with SLE and had received prednisolone and mizoribine treatment. Although symptoms ameliorated immediately, $\mathrm{CH} 50$ remained consistently negative during a period of six months, whereas $\mathrm{C} 3$ and $\mathrm{C} 4$ were within the normal range. Antinuclear antibody and rheumatoid factor levels gradually elevated, but anti-double stranded DNA IgG antibody levels were still negative. From the above discrepancy between symptoms and laboratory data changes, we suspected complement deficiency so investigated her complement system in detail. Serum C1q levels measured at SRL Inc. (Tokyo, Japan) by nephelometry were $2.8 \mathrm{mg} / \mathrm{dl}$ (normal range: $8.8-15.3 \mathrm{mg} / \mathrm{dl}$ ). Further analysis of the complement systems revealed that whole alternative complement pathway activity (ACH50) and $\mathrm{C} 4$ and $\mathrm{C} 2$ activities were within the normal range, whereas $\mathrm{C} 1$ activity was very low (Table 2 ) [10-13]. The addition of purified human C1 subcomponent enabled $\mathrm{CH} 50$ to be restored to a normal range only when $\mathrm{C} 1 \mathrm{q}$ was added, but neither $\mathrm{C} 1 \mathrm{r}$ nor $\mathrm{C} 1 \mathrm{~s}$ was effective (Table 3). For this reason, we strongly suspected a C1q deficiency.

Genomic DNA was extracted from EDTA-blood cells using standard procedures. PCR primers were designed to amplify all exons and exon-intron boundaries of $C 1 q A, C 1 q B$ and $C 1 q C$ genes. Table 4 shows the primer sets and sequencing performed with the BigDye terminator v3.1 Cycle Sequencing Kit. Sequence analysis revealed a novel homozygous splice site mutation in $C 1 q B$, c. $187+1 \mathrm{G}>\mathrm{T}$ (Figure 2), but no other mutations. Reverse transcriptase-polymerase chain reaction amplification of $C 1 q B$ demonstrated the presence of an abnormal single band on gel electrophoresis caused by a splicing error of intron 2/intron 3 (Figure 3). Combined with the complement assay, this DNA sequencing result enabled the molecular diagnosis of $\mathrm{Clq}$ deficiency to be confirmed. Mutation analysis and $\mathrm{CH} 50$ measurements of family members demonstrated that the patient's parents and one sibling were heterozygous for c. $187+1 \mathrm{G}>\mathrm{T}$ with normal $\mathrm{CH} 50$ levels. The second sibling (0 years old) with undetectable $\mathrm{CH} 50$ levels was also homozygous for the mutation (Figure 4).

After about one year from the first visit, the patient experienced a recurrent fever every few days with no 
Table 1 Laboratory findings on first visit of patient

\begin{tabular}{|c|c|c|c|c|c|}
\hline Blood test & Result & Normal range & Blood test & Result & Normal range \\
\hline WBC & $6600 / \mu l$ & $4500-15500$ & CRP & $1.32 \mathrm{mg} / \mathrm{dl}$ & $<0.1$ \\
\hline Seg & $5600 / \mu l$ & $1500-8500$ & ESR $60 \mathrm{~min}$ & $65 \mathrm{~mm} / 60 \mathrm{~min}$ & $0-15$ \\
\hline Ly & $660 / \mu l$ & $1200-8000$ & & & \\
\hline $\mathrm{RBC}$ & $379 \times 10^{4} / \mu l$ & $390-490$ & $\mathrm{CH} 50$ & $<12.0 \mathrm{CH} 50 / \mathrm{ml}$ & $22-40$ \\
\hline $\mathrm{Hb}$ & $10.7 \mathrm{~g} / \mathrm{dl}$ & $11.4-14.2$ & C3 & $122 \mathrm{mg} / \mathrm{dl}$ & $71-159$ \\
\hline $\mathrm{Ht}$ & $30.5 \%$ & $34-40$ & C4 & $45 \mathrm{mg} / \mathrm{dl}$ & $13-30$ \\
\hline Plt & $15.2 \times 10^{4} / \mu \mathrm{l}$ & $14.0-45.0$ & RF & $31 \mathrm{IU} / \mathrm{ml}$ & $<40$ \\
\hline AST & $31 \mathrm{IU} / \mathrm{I}$ & $18-63$ & ANA(speckled) & 1:320 & $<1: 40$ \\
\hline ALT & $21 \mathrm{IU} / \mathrm{I}$ & $20-50$ & Anti-dsDNA IGG & $<10 \mathrm{IU} / \mathrm{ml}$ & $<10$ \\
\hline $\mathrm{LDH}$ & $297 \mathrm{IU} / \mathrm{I}$ & $142-297$ & Anti-Sm & $1: 2$ & $<1: 2$ \\
\hline $\mathrm{Na}$ & 141 mEq/l & $134-143$ & Anti-RNP & $1: 16$ & $<1: 2$ \\
\hline K & $3.3 \mathrm{mEq} / \mathrm{l}$ & $3.4-4.9$ & Anti-Ro & $(-)$ & $(-)$ \\
\hline $\mathrm{Cl}$ & 104 mEq/l & 98-107 & Anti-La & $(-)$ & $(-)$ \\
\hline $\mathrm{Ca}$ & $9.0 \mathrm{mg} / \mathrm{dl}$ & $8.8-10.3$ & & & \\
\hline $\mathrm{TP}$ & $6.3 \mathrm{~g} / \mathrm{dl}$ & $5.6-7.7$ & Urinalysis & & \\
\hline Alb & $3.8 \mathrm{~g} / \mathrm{dl}$ & $3.1-4.8$ & U-protein & $(-)$ & $(-)$ \\
\hline BUN & $6 \mathrm{mg} / \mathrm{dl}$ & $5-27$ & U-glucose & $(-)$ & $(-)$ \\
\hline Cre & $0.40 \mathrm{mg} / \mathrm{dl}$ & $0.30-0.90$ & U-occult blood & $(-)$ & $(-)$ \\
\hline
\end{tabular}

sign of infection. Despite increasing the doses of prednisolone (15 mg/day) and mizoribine (300 mg/every other day), fever and erythematosus rash were aggravated and the ESR elevated to $68 \mathrm{~mm} / 60 \mathrm{~min}$, which is the index that most reflects her condition. We carried out intravenous methylprednisolone pulse therapy, but the effect was only temporary. Accordingly, we initiated fresh frozen plasma (FFP) transfusion for supplementation of $\mathrm{C} 1 \mathrm{q}$. Immediately after transfusion of FFP $(10 \mathrm{ml} / \mathrm{kg})$, her $\mathrm{CH} 50$ levels recovered to within the normal range but became undetectable $24 \mathrm{~h}$ later (Table 5). Nevertheless, she remained afebrile and her rash improved slowly, while ESR declined to $37 \mathrm{~mm} /$ 60 min following once weekly administration of FFP

Table 2 Analysis of complement system activity

\begin{tabular}{cccc}
\hline Hemolytic activity & NHS & Patient serum & Reference value \\
\hline CH50 (U/ml) & 125 & 0 & $90-160$ \\
(NHS \%) & $100 \%$ & $0 \%$ & \\
ACH50 (U/ml) & 18.5 & 18.9 & $70-130 \%$ \\
(NHS \%) & $100 \%$ & $102 \%$ & \\
C1 activity (U/ml) & 1450 & 100 & $70-130 \%$ \\
(NHS \%) & $100 \%$ & $7 \%$ & $70-130 \%$ \\
C2 activity (U/ml) & 400 & 360 & \\
(NHS \%) & $100 \%$ & $90 \%$ & $70-130 \%$ \\
C4 activity (U/ml) & 2000 & 1600 & \\
(NHS \%) & $100 \%$ & $80 \%$ & \\
\hline
\end{tabular}

NHS normal human serum, $A C H 50$ alternative complement pathway activity.
$(10 \mathrm{ml} / \mathrm{kg})$. We are currently attempting to slowly reduce the prednisolone dosage and the frequency of FFP.

\section{Conclusions}

We report a girl diagnosed with SLE because of C1q deficiency caused by a novel homozygous splice site mutation in $C 1 q B$. C1q deficiency is a rare autosomal recessively inherited disease, with only 41 patients from 23 families reported in 1998 [2]. More recently, $\mathrm{C} 1 \mathrm{q}$ deficiency has been confirmed in 64 cases within 38 families, $88 \%$ of which present with SLE or SLElike disease [7].

Table 3 Addition of purified human C1 subcomponent

\begin{tabular}{cc}
\hline Hemolytic activity & NHS \\
\hline CH50 (U/ml) & 125 \\
(NHS \%) & $100 \%$ \\
Patient serum + C1q (U/ml) & 140 \\
Patient serum + C1r (U/ml) & $112 \%$ \\
(NHS \%) & 0 \\
Patient serum + C1s (U/ml) & $0 \%$ \\
(NHS \%) & 0 \\
Patient serum + activated C1s (U/ml) $\%)$ & 0 \\
\hline NHS normal human serum. & $0 \%$ \\
\hline
\end{tabular}


Table 4 List of primers used in this work

\begin{tabular}{|c|c|c|c|c|c|c|}
\hline Primer name & Gene & Exon & $F / R$ & Primer sequence $\left(5^{\prime}-3^{\prime}\right)$ & $\operatorname{Tm}\left({ }^{\circ} \mathrm{C}\right)$ & Annealing $\operatorname{Tm}\left({ }^{\circ} \mathrm{C}\right)$ \\
\hline C1QA-02-F & $\mathrm{C} 1 \mathrm{qA}$ & 02 & $\mathrm{~F}$ & TTGTGTGCATGGGACTCAAG & 56 & 60 \\
\hline C1QA-02-R & $\mathrm{C} 1 \mathrm{qA}$ & 02 & $\mathrm{R}$ & GGCCAAGTCAGGCCAAG & 58 & \\
\hline C1QA-03a-F & $\mathrm{C} 1 \mathrm{qA}$ & 03a & $\mathrm{F}$ & TCCCTGAGGACCAGTAGGC & 60 & 60 \\
\hline C1QA-03a-R & $\mathrm{C} 1 \mathrm{qA}$ & 03a & $\mathrm{R}$ & GGACAGGCAGATTTCCCAC & 58 & \\
\hline C1QA-03b-F & $\mathrm{C} 1 \mathrm{qA}$ & $03 b$ & $\mathrm{~F}$ & TCATCTTCGACACGGTCATC & 56 & 60 \\
\hline C1QA-03b-R & $\mathrm{C} 1 \mathrm{qA}$ & 03b & $\mathrm{R}$ & ATTTACAGGCGGAGCATGG & 56 & \\
\hline C1QB-02-F & $\mathrm{C} 1 \mathrm{qB}$ & 02 & $\mathrm{~F}$ & GGATGCAGATGGAGGGATAG & 58 & 60 \\
\hline C1QB-02-R & $\mathrm{C} 1 \mathrm{qB}$ & 02 & $\mathrm{R}$ & AGGCAACTGTGACTTGGGAG & 58 & \\
\hline C1QB-03a-F & $\mathrm{C} 1 \mathrm{qB}$ & 03a & $\mathrm{F}$ & GCAGGCCTCCTTCTITTGG & 58 & 60 \\
\hline C1QB-03a-R & $\mathrm{C} 1 \mathrm{qB}$ & 03a & $\mathrm{R}$ & TCACGCACAGGTTCCCTC & 58 & \\
\hline C1QB-03b-F & $\mathrm{ClqB}$ & 03b & $\mathrm{F}$ & CAGACCATCCGCTTCGAC & 58 & 60 \\
\hline C1QB-03b-R & $\mathrm{C} 1 \mathrm{qB}$ & 03b & $\mathrm{R}$ & GGGGTAGAGTGAGCGTTGC & 60 & \\
\hline C1QC-02-F & $\mathrm{ClqC}$ & 02 & $\mathrm{~F}$ & ATCCATGGTGAGGCTCCTG & 58 & 60 \\
\hline C1QC-02-R & $\mathrm{ClqC}$ & 02 & $\mathrm{R}$ & CCCAGACAGACACTCTGATCC & 60 & \\
\hline C1QC-03a-F & $\mathrm{C} 1 \mathrm{qC}$ & 03a & $\mathrm{F}$ & GTTCCCTGGAAGACACCCTC & 60 & 60 \\
\hline C1QC-03a-R & $\mathrm{ClqC}$ & 03a & $\mathrm{R}$ & TATGCGACGCGTGGTAGAC & 58 & \\
\hline C1QC-03b-F & $\mathrm{C} 1 \mathrm{qC}$ & 03b & $\mathrm{F}$ & AGCCTGATCAGATTCAACGC & 56 & 60 \\
\hline C1QC-03b-R & $\mathrm{C} 1 \mathrm{qC}$ & 03b & $\mathrm{R}$ & TGGCCAGTAAGGTGGGTCC & 60 & \\
\hline
\end{tabular}

$F$ forward, $R$ reverse, $T m$ temperature.

There are three hypotheses regarding the relationship between C1q deficiency and SLE or SLE-like disease. The first is that $\mathrm{C} 1 \mathrm{q}$ deficiency causes autoimmunity by impairing the clearance of apoptotic cells [2], while in the second the absence of $\mathrm{Clq}$ affects the negative selection of autoreactive $\mathrm{B}$ cells [14]. The third is that the lack of $\mathrm{C} 1 \mathrm{q}$ leads to increased interferon- $\alpha$ production and the defective regulation of dendritic cells [15]. It has also been reported that $\mathrm{C} 1 \mathrm{q}$ activates canonical Wnt signaling, which regulates $\mathrm{T}$ cell development and dendritic cell maturation [16-18]. The suppression of Wnt signaling in association with $\mathrm{C} 1 \mathrm{q}$ deficiency may result in the inadequate activation of lymphocytes.

The majority of C1q deficiency patients are European or Middle Eastern, with only four cases reported to
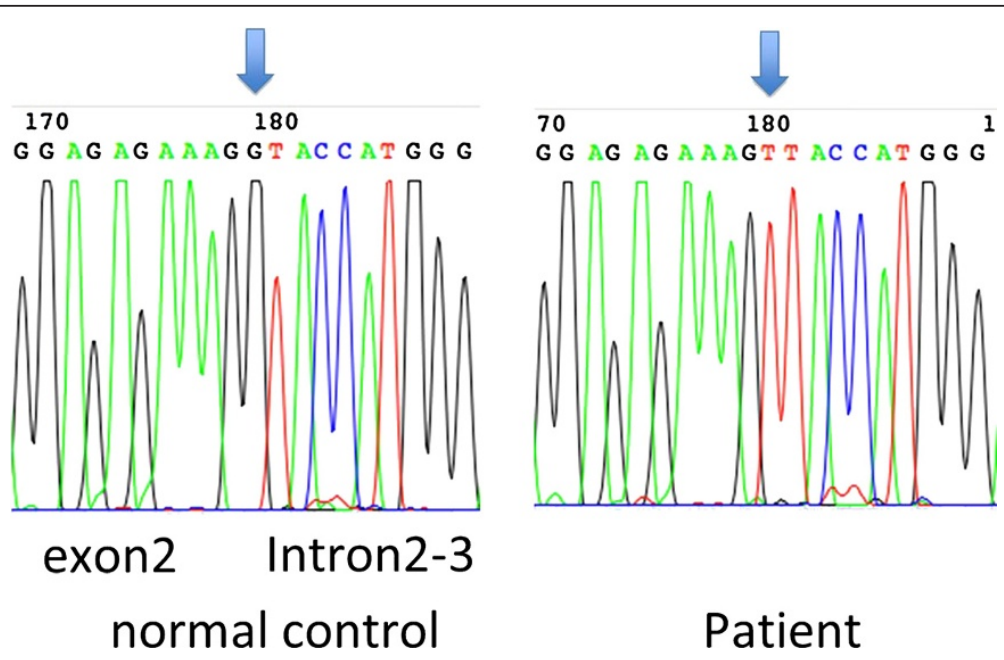

\section{Patient}

Figure 2 Sequence analysis of the $C 1 q B$ gene. A homozygous mutation was identified at the consensus splicing donor site in intron 2-3 caused by a G-to-T transversion (c.187 + 1G > T). 


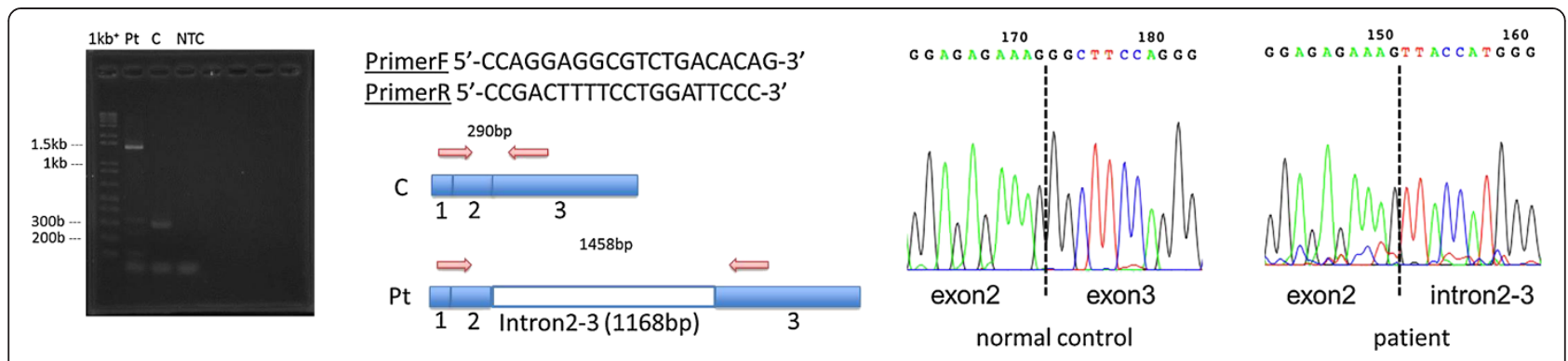

Figure 3 Reverse transcriptase-polymerase chain reaction analysis of C1qB mRNA. A single band observed at 1458 bp was caused by a splicing error of intron 2-3. 1 kb+, 1,000 bp DNA-ladder marker; Pt., patient; C., normal control; NTC, no template control.

date in Japan, none of which were confirmed by genetic analysis [7,19-22]. Al-Mayouf et al. reported that C1q deficiency patients tend to develop SLE in less than five years [4]. Our patient also developed SLE at the age of four, with persistent hypocomplementemia and normal C3 and C4 levels. We believe that the possibility of $\mathrm{C} 1 \mathrm{q}$ deficiency should therefore always be considered in such cases. To our knowledge, 14 different C1q deficiency-causing mutations have been identified to date, most in European and Middle Eastern patients, with one in an African-American ancestry [7-9]. All are missense or nonsense mutations, so the present mutation is the first report of a splicing error associated with the disorder.

Previously reported complications of C1q deficiency include glomerulonephritis in $30 \%$, central nervous system involvement in 19\%, and bacterial infections in $41 \%$ of patients [7]. Moreover, symptoms present with

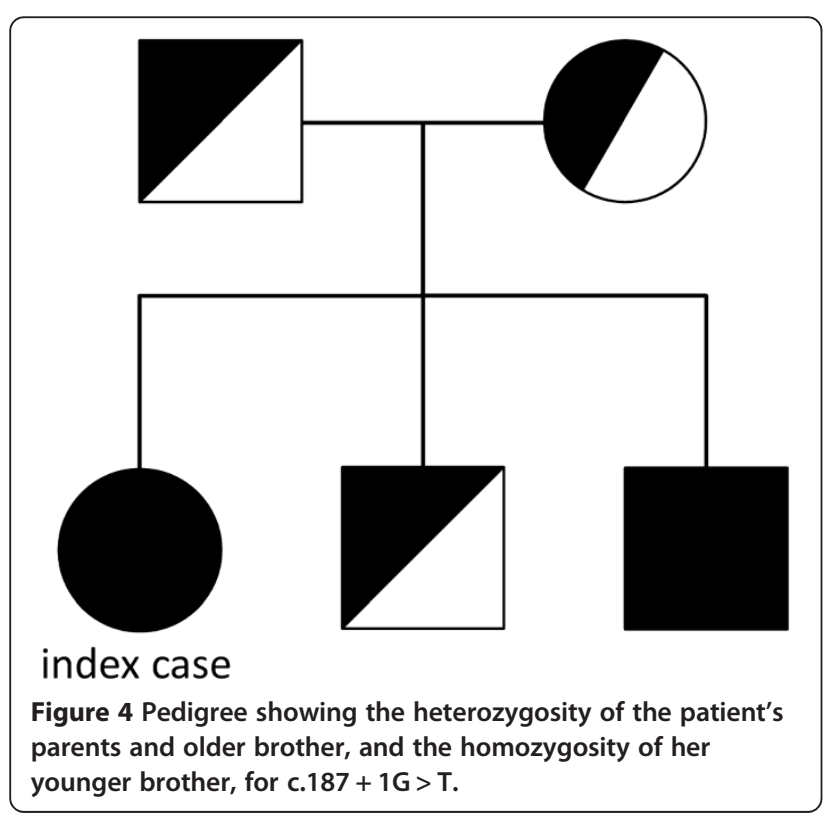

varying degrees of severity, even in the same family [23]. It is possible that environmental factors such as exposure to ultraviolet radiation or a history of infection may affect the epigenetic regulation of developing SLE-like syndrome. In our case, the patient may develop complications later in life, and her homozygous sibling may also develop SLE. It is therefore important to carefully follow up our patients to prevent the onset of glomerulonephritis and central nervous system involvements.

At present, no specific therapy is available for $\mathrm{C} 1 \mathrm{q}$ deficiency, so steroids and immunosuppressive agents such as hydroxychloroquine (not currently available in Japan) are used as treatments. Bone marrow transplantation is a potential cure, but it has not yet been performed in humans [24,25]. Some reports show that the infusion of FFP restores C1q levels, temporarily complements hemolytic activity, and suppresses SLE symptoms for a long period $[8,24]$. It is therefore a valid therapy for $\mathrm{C} 1 \mathrm{q}$ deficiency patients. However, the long-term administration of FFP increases the risk of infection and the possibility of side effects caused by the development of anti-C1q antibodies [26]. In the light of such risks, alternative treatment strategies should be considered for this intractable disease.

\section{Consent}

Written informed consent was obtained from the patient for publication of this Case Report and any accompanying images. A copy of the written consent is available for review from the Editor-in-Chief of this journal.

Table 5 Measurement of CH50 following transfusion of FFP in the patient

\begin{tabular}{lcccc}
\hline Time $(\mathrm{hr})$ & $\mathbf{0}$ & $\mathbf{3}$ (end of transfusion) & $\mathbf{9}$ & $\mathbf{2 4}$ \\
\hline $\mathrm{CH} 50(\mathrm{U} / \mathrm{ml})$ & $<12.0$ & 25.5 & 24.6 & $<12.0$ \\
\hline
\end{tabular}




\section{Abbreviations}

SLE: Systemic lupus erythematosus; ESR: Erythrocyte sedimentation rate; CRP: C-reactive protein; CH50: Total complement activity; CT: Computed tomography; FFP: Fresh frozen plasma.

\section{Competing interests}

The authors have nothing to disclose.

\section{Authors' contributions}

$\mathrm{YH}$ drafted the manuscript, and participated in treatment. JS, KA, and TK carried out the clinical treatment and helped draft the manuscript. $\mathrm{MH}$, EK, and $\mathrm{HK}$ analyzed the complement systems and interpreted the data. HT, MI, $\mathrm{TH}$, and $\mathrm{OO}$ sequenced the Clq genes and performed reverse transcriptasepolymerase chain reaction analysis of $C 1 q B$ mRNA. All authors read and approved the final manuscript.

\section{Acknowledgement}

We thank Edanz (http://www.edanzediting.co.jp) for English writing assistance.

\section{Author details}

'Department of Pediatrics, National Hospital Organization Okayama Medical Center, 1711-1 Tamasu, Kita-ku, Okayama 701-1192, Japan. ²Department of Medical Technology Faculty of Health Sciences, Kobe Tokiwa University, 2-6-2 Ohtanicho, Nagata-ku, Kobe 653-0838, Japan. ${ }^{3}$ Department of Pediatrics, Graduate School of Medical Sciences, Kyushu University, 3-1-1 Maidashi, Higasi-ku, Fukuoka 812-8582, Japan. ${ }^{4}$ Department of Human Genome Technology, Kazusa DNA Research Institute, 2-6-7 Kazusakamatari, Chiba 292-0818, Japan. ${ }^{5}$ Department of Dermatology, National Hospital Organization Okayama Medical Center, 1711-1 Tamasu, Kita-ku, Okayama 701-1192, Japan.

Received: 13 August 2013 Accepted: 25 October 2013 Published: 28 October 2013

\section{References}

1. Kishore U, Reid KB: C1q: structure, function, and receptors. Immunopharmacology 2000, 49:159-170

2. Walport MJ, Davies KA, Botto M: C1q and systemic lupus erythematosus. Immunobiology 1998, 199:265-285.

3. Walport MJ: Complement and systemic lupus erythematosus. Arthritis Res 2002, 4(Suppl 3):279-293

4. Al-Mayouf SM, Abanomi H, Eldali A: Impact of C1q deficiency on the severity and outcome of childhood systemic lupus erythematosus. Int $\mathrm{J}$ Rheum Dis 2011, 14:81-85.

5. Pickering MC, Botto M, Taylor PR, Lachmann PJ, Walport MJ: Systemic lupus erythematosus, complement deficiency, and apoptosis. Adv Immunol 2000, 76:227-324.

6. McAdam RA, Goundis D, Reid KB: A homozygous point mutation results in a stop codon in the C1q B-chain of a C1q-deficient individual. Immunogenetics 1988, 27:259-264.

7. Schejbel L, Skattum L, Hagelberg S, Åhlin A, Schiller B, Berg S, Genel F, Truedsson L, Garred P: Molecular basis of hereditary C1q deficiencyrevisited: identification of several novel disease-causing mutations. Genes Immun 2011, 12:626-634.

8. Namjou B, Keddache M, Fletcher D, Dillon S, Kottyan L, Wiley G, Gaffney PM, Wakeland BE, Liang C, Wakeland EK, Scofield RH, Kaufman K, Harley JB: Identification of novel coding mutation in C1qA gene in an AfricanAmerican pedigree with lupus and C1q deficiency. Lupus 2012, 21:1113-1118

9. Topaloglu R, Taskiran EZ, Tan C, Erman B, Ozaltin F, Sanal O: C1q deficiency: identification of a novel missense mutation and treatment with fresh frozen plasma. Clin Rheumatol 2012, 31:1123-1126.

10. Kobayashi $\mathrm{E}$, Kitano $\mathrm{E}$, Kitamura $\mathrm{H}$ : A novel assay for serum complement activity: C42 generation assay. Int Arch Allergy Immunol 1999, 120:71-77.

11. Kitamura H, Nishimukai H, Sano Y, Nagaki K: Study on C3-like factor in the serum of a C3-deficient subject. Immunology 1984, 51:239-245.

12. Kitano E, Kitamura H: Dual effects of TNF on synthesis of complement components by a gastric cancer-derived cell line, KATO-III. Int Arch Allergy Immunol 1999, 119:54-59.
13. Whaley K, North J: Haemolytic assays for whole complement activity and individual components. In Complement: A Practical Approach. Edited by Dodds AW, Sim RB. Oxford: IRL Press; 1997:19-47.

14. Yurasov S, Wardemann H, Hammersen J, Tsuiji M, Meffre E, Pascual V, Nussenzweig MC: Defective B cell tolerance checkpoints in systemic lupus erythematosus. J Exp Med 2005, 201:703-711.

15. Santer DM, Hall BE, George TC, Tangsombatvisit S, Liu CL, Arkwright PD, Elkon KB: C1q deficiency leads to the defective suppression of IFN-alpha in response to nucleoprotein containing immune complexes. J Immunol 2010, 185:4738-4749.

16. Naito AT, Sumida T, Nomura S, Liu ML, Higo T, Nakagawa A, Okada K, Sakai T, Hashimoto A, Hara Y, Shimizu I, Zhu W, Toko H, Katada A, Akazawa H, Oka T, Lee JK, Minamino T, Nagai T, Walsh K, Kikuchi A, Matsumoto M, Botto M, Shiojima I, Komuro I: Complement C1q activates canonical Wnt signaling and promotes aging-related phenotypes. Cell 2012, 149:1298-1313.

17. Manicassamy S, Reizis B, Ravindran R, Nakaya H, Salazar-Gonzalez RM, Wang YC, Pulendran B: Activation of beta-catenin in dendritic cells regulates immunity versus tolerance in the intestine. Science 2010, 329:849-853.

18. Xu Y, Banerjee D, Huelsken J, Birchmeier W, Sen JM: Deletion of betacatenin impairs T cell development. Nat Immunol 2003, 4:1177-1182.

19. Nishino H, Shibuya K, Nishida Y, Mushimoto M: Lupus erythematosus-like syndrome with selective complete deficiency of C1q. Ann Intern Med 1981, 95:322-324.

20. Uenaka A, Akimoto T, Aoki T, Tsuyuguchi I, Nagaki K: A complete selective C1q deficiency in a patient with discoid lupus erythematosus (DLE). Clin Exp Immunol 1982, 48:353-358.

21. Orihara T, Tsuchiya K, Yamasaki S, Furuya T: Selective C1q deficiency in a patient with systemic lupus erythematosus. Br J Dermatol 1987, 117:247-254.

22. Hayakawa J, Migita M, Ueda T, Itoh Y, Fukunaga Y: Infantile case of early manifestation of SLE-like symptoms in complete C1q deficiency. J Nippon Med Sch 2011, 78:322-328.

23. Vassallo G, Newton RW, Chieng SE, Haeney MR, Shabani A, Arkwright PD: Clinical variability and characteristic autoantibody profile in primary $\mathrm{C} 1 \mathrm{q}$ complement deficiency. Rheumatology (Oxford) 2007, 46:1612-1614.

24. Mehta P, Norsworthy PJ, Hall AE, Kelly SJ, Walport MJ, Botto M, Pickering MC: SLE with C1q deficiency treated with fresh frozen plasma: a 10-year experience. Rheumatology (Oxford) 2010, 49:823-824.

25. Cortes-Hernandez J, Fossati-Jimack L, Petry F, Loos M, Izui S, Walport MJ, Cook HT, Botto M: Restoration of C1q levels by bone marrow transplantation attenuates autoimmune disease associated with $\mathrm{C} 1 \mathrm{q}$ deficiency in mice. Eur J Immunol 2004, 34:3713-3722.

26. Bowness P, Davies KA, Norsworthy PJ, Athanassiou P, Taylor-wiedeman J, Borysiewicz LK, Meyer PAR, Walport MJ: Hereditary C1q deficiency and systemic lupus erythematosus. QJM 1994, 87:455-464.

doi:10.1186/1546-0096-11-41

Cite this article as: Higuchi et al:: The identification of a novel splicing mutation in $C 1 q B$ in a Japanese family with C1q deficiency: a case report. Pediatric Rheumatology 2013 11:41.

\section{Submit your next manuscript to BioMed Central and take full advantage of:}

- Convenient online submission

- Thorough peer review

- No space constraints or color figure charges

- Immediate publication on acceptance

- Inclusion in PubMed, CAS, Scopus and Google Scholar

- Research which is freely available for redistribution 